\title{
Eelgrass Zostera marina in subarctic Greenland: dense meadows with slow biomass turnover in cold waters
}

\author{
Birgit Olesen ${ }^{1, *}$, Dorte Krause-Jensen ${ }^{2,3}$, Núria Marbà ${ }^{4}$, Peter Bondo Christensen ${ }^{2,3}$ \\ ${ }^{1}$ Department of Bioscience, Aarhus University, Ole Worms Allé 1, Building 1135, 8000 Aarhus C, Denmark \\ ${ }^{2}$ Department of Bioscience, Aarhus University, Vejlsøvej 25, 8600 Silkeborg, Denmark \\ ${ }^{3}$ Arctic Research Centre, Aarhus University, C.F. Møllers Allé 8, 8000 Aarhus C, Denmark \\ ${ }^{4}$ Department of Global Change Research, IMEDEA (CSIC-UIB), Institut Mediterrani d'Estudis Avancats, Miquel Marques 21, \\ 07190 Esporles (Illes Balears), Spain
}

\begin{abstract}
Eelgrass Zostera marina L. is the most dominant seagrass species throughout the temperate northern hemisphere, and knowledge on its distribution and production in relation to climatic conditions is relevant for predicting the future of the meadows. We synthesized past and present information on eelgrass near the northern distribution limit in Greenland, and quantified the biomass, production and reproductive potential of eelgrass populations in 4 widely separated locations of Godthåbsfjorden at $64^{\circ} \mathrm{N}$. Eelgrass observations in Greenland date back to 1813 ; most of the meadows recorded in the past still exist, and new ones were identified. The meadows are relatively small and geographically isolated, typically occurring in inner branches of the fjord system where summer water temperatures are higher $\left(13\right.$ to $\left.15^{\circ} \mathrm{C}\right)$ than in the outer part $\left(<10^{\circ} \mathrm{C}\right)$. The shoot density ( 871 to 2045 shoots $\mathrm{m}^{-2}$ ), aboveground biomass (90 to $327 \mathrm{~g}$ dry wt [DW] $\mathrm{m}^{-2}$ ) and rhizome extension rates ( 8 to $29 \mathrm{~cm} \mathrm{yr}^{-1}$ ) match levels further south. By contrast, the annual production of 7 to 13 leaves shoot ${ }^{-1}$ is considerably lower and leads to slow leaf biomass turnover (1.6 to $\left.2.6 \mathrm{yr}^{-1}\right)$ in these northern populations. Even though flowering was common, mature seeds were found only once, after a warm summer, and no seedlings were observed. An analysis of published data on eelgrass leaf biomass and production across the entire species distribution range revealed that leaf biomass is not affected by either latitude or air temperature, whereas annual leaf formation rates are significantly lower in cold areas at high latitude compared to warm areas at low latitude. The results suggest that distribution and production in Greenland are currently limited by low temperature and likely to increase in a warmer future.
\end{abstract}

KEY WORDS: Biomass - Climate change - Greenland · Production · Seagrass - Sub-arctic · Zostera marina

Resale or republication not permitted without written consent of the publisher

\section{INTRODUCTION}

Eelgrass Zostera marina L. is the most abundant seagrass species of the northern hemisphere (den Hartog 1970), and is considered a key species along soft-bottom coastlines. The dense and typically monospecific stands contribute to carbon storage, nutrient retention, sediment stabilization, improve- ment of water clarity and enhanced biodiversity (van der Heide et al. 2007, McGlathery et al. 2012). Eelgrass is distributed over a wide latitudinal range $(\sim 5000 \mathrm{~km})$ from warm subtropical regions of the eastern Pacific $\left(26^{\circ} \mathrm{N}\right.$, Gulf of California) in the south to arctic regions in the north (Ostenfeld 1927, den Hartog 1970, Cabello-Pasini et al. 2003, Green \& Short 2003). It has been observed as far north as the 
White Sea at $66^{\circ} \mathrm{N}$ (Jacobs 1984), along Norway's coast to $70^{\circ} \mathrm{N}$ (Ostenfeld 1927), on Iceland at $\sim 64^{\circ} \mathrm{N}$ (Boström et al. 2014), in the Hudson Bay-Ungava Bay region, Canada, at $\sim 60^{\circ} \mathrm{N}$ (Cottam \& Munro 1954) and in the Bering Strait, Alaska, at $65^{\circ} \mathrm{N}$ (Porsild 1932, McRoy 1968). There are also scattered past observations and anecdotal records of eelgrass at latitudes as far north as $70^{\circ} \mathrm{N}$ in Greenland (Lange 1890, Hartz 1901), but until now the eelgrass meadows of Greenland have never been studied quantitatively.

The broad latitudinal gradient experienced by eelgrass implies a large tolerance to climatic conditions characterized by increasing variation in irradiance and seasonal changes in daylength, as well as decreasing temperature going from south to north. Temperature is generally considered a key factor defining the distribution ranges of species (Woodward \& Williams 1987), including marine vegetation species (e.g. McQuaid \& Branch 1984, Dring 1992, Müller et al. 2009, Wulff et al. 2009). Due to its widespread distribution, eelgrass experiences temperatures ranging from below $0^{\circ} \mathrm{C}$ to over $30^{\circ} \mathrm{C}$ (Phillips \& Backman 1983, Orth \& Moore 1986), but with optimum temperatures for growth typically occurring at temperatures ranging from 15 to $20^{\circ} \mathrm{C}$ (Zimmerman et al. 1989, Nejrup \& Pedersen 2008). While established eelgrass plants can thrive for extended periods in cold waters, extremely high temperature can only be tolerated for relatively short periods, and high summer temperatures are considered to set the biogeographical boundary at the species' southern range limits. High water temperatures decrease growth and increase mortality, and these negative effects may be exacerbated by the interaction with other stressors such as reduced light availability, low salinity, or low oxygen levels (Olesen \& Sand-Jensen 1993, Nejrup \& Pedersen 2008, Moore et al. 2012, 2014, Raun \& Borum 2013). Hence, diebacks have been recorded at summer temperatures above $25^{\circ} \mathrm{C}$ (Orth \& Moore 1986, Sfriso \& Ghetti 1998, Moore \& Jarvis 2008), and at the southern distribution limit eelgrass populations may adopt an annual or a mixed-annual life strategy to escape the warm summertime conditions (Phillips \& Backman 1983, Meling-López \& Ibarra-Obando 1999, Jarvis et al. 2012). Water temperature also affects the timing of life-history events with progressively later flowering and seed maturation at increasing latitudes (Phillips et al. 1983, Silberhorn et al. 1983). It is therefore likely that the cold summer temperatures at high latitudes limit the reproductive capacity and dispersal of eelgrass and thereby contribute to defining the northernmost distribution limit (Setchell 1929).
The northern range limit of eelgrass may also be influenced by low annual light availability, primarily determined by the short daylengths, low solar elevation, and ice cover during winter. In perennial eelgrass meadows, the light energy needed to support photosynthetic carbon production must balance respiratory carbon losses on an annual basis. Hence, the ability of eelgrass to store carbon reserves in rhizomes during the summer period of abundant light availability is critical to meet metabolic demands during the dark winter months (Zimmerman et al. 1989), and probably accounts for the fact that eelgrass indeed can survive long periods of darkness under sea ice (McRoy 1969). Prolonged periods of winter darkness may, however, affect eelgrass growth negatively, as suggested by the inverse relationship between annual net production and the duration of ice cover in arctic freshwater mosses and marine macroalgae (Krause-Jensen et al. 2012, Riis et al. 2014).

The large influence of light and temperature on eelgrass survival, growth and reproduction implies that spatial, as well as temporal, variations in climatic conditions should markedly affect eelgrass meadows and their associated functions. At the distribution boundaries where eelgrass grows at the physiological limits of existence, even subtle changes in light and temperature conditions during particular stages in the life cycle may have pronounced biological effects. The current warming of the globe is occurring twice as fast in the Arctic as for the globe on average (IPCC 2007), rendering the Arctic particularly susceptible to the effects of climate change. While several studies have documented the negative effects of high temperatures on seagrass growth and survival at lower latitudes (Thayer et al. 1984, SantamaríaGallegos et al. 2000, Nejrup \& Pedersen 2008, Bergmann et al. 2010), knowledge on productivity, growth and reproduction of eelgrass and probable responses to warming are lacking in the typically colder climates at the northern distribution limit (McRoy 1974, Duarte et al. 2002, Berger 2011, Jørgensen \& Bkkby 2013, Olsen et al. 2013).

In this study, we aim to characterize eelgrass meadows near the northern distribution limit in Greenland where growing seasons are short and current summer temperatures are below the optimum temperatures reported for eelgrass growth in warmer, temperate waters (e.g. Zimmerman et al. 1989, Nejrup \& Pedersen 2008). More specifically we aim to (1) synthesize the existing information on past and present observations of eelgrass in Greenland; (2) quantify biomass, shoot density, annual leaf production, rhizome pro- 
duction and reproductive potential of eelgrass populations in 4 different fjord arms of the Godthåbsfjord system; (3) evaluate differences in biomass and annual leaf production of eelgrass across the species' geographical distribution range; and (4) discuss the potential effects of increasing temperature on eelgrass growth, reproduction and distribution in Greenland as a result of global climate change.

\section{METHODS}

\section{Compilation of existing information}

We compiled historic information on eelgrass (Zostera marina) distribution in Greenland from published literature and herbarium specimens kept in the Greenland Herbarium, Botanical Museum, University of Copenhagen. Year of observation, location and geographic coordinates (when given) were noted. Information on present-day distribution was gathered from residents in Greenland. Several local fishermen and boat owners were informally interviewed about the existence of eelgrass meadows. This was useful because there are no formal records of eelgrass distribution in the more remote areas along the Greenland coastline.

The literature search also targeted quantification of eelgrass leaf biomass and annual leaf formation rate across the entire geographical distribution range for comparison with the Greenland data. We restricted our analysis to include eelgrass meadows in water shallower than $4 \mathrm{~m}$, and most $(80 \%)$ were from $<2 \mathrm{~m}$ depth. The compiled biomass data were sampled within bottom areas of 0.01 to $0.25 \mathrm{~m}^{2}$ and in 2 to 10 replicates per meadow. Annual leaf formation rates were obtained with leaf marking techniques or by reconstructing past growth from leaf marks on the rhizomes. For evaluation of seasonal biomass maxima we only included data from investigations with frequent measurements (less than 2 mo intervals) during the summer period, except for the biomass data collected in Alaska (McRoy 1969, 1970), Hudson Bay (Lalumière et al. 1994) and Greenland (this study), where samples were collected once within the period from July to September. To assess whether variability among populations reflected latitude or temperature, site-specific average summer (June to August) air temperatures were derived from the Worldclim dataset (period 1950 to 2000; www.worldclim.org). We used air temperature as a substitute for sea-water temperature because local monthly water temperatures were not always provided in the cited literature. Previous studies show a close correlation between air and water temperature (Cabello-Pasini et al. 2003, Lee et al. 2006), although deviations occur due to factors such as local sea currents, upwelling of cool water to the sea surface and river runoff. The geographical coordinates were obtained either directly from the cited literature or deduced from the descriptions of the sampling sites.

\section{Study area}

The field study was conducted in the Godthåbsfjord system near Nuuk $\left(64^{\circ} \mathrm{N}\right)$, the capital of Greenland, where most of the historic and present observations of eelgrass originated (Fig. 1). The fjord system is composed of a mosaic of bays and fjord branches representing a wide diversity of physico-chemical conditions with respect to influence by glacial melt water, seasonal cover of sea ice, water temperature, exposure to wind and ice scour, bathymetry and bot-

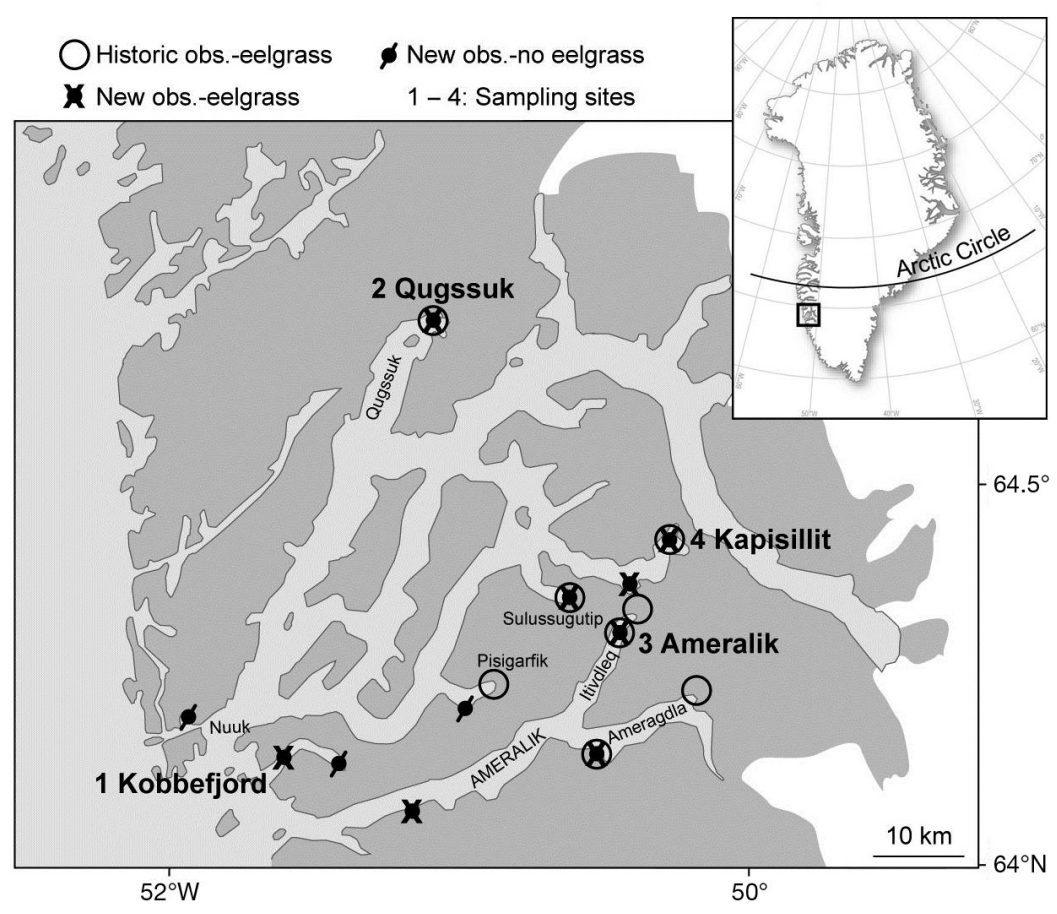

Fig 1. Eelgrass (Zostera marina) observations in the Godthåbsfjord system. O: eelgrass meadows recorded between 1830 and 1973 ; $\mathbf{X}$ : observations from the present study; : eelgrass that was searched for in the present study but not found. White areas indicate the Greenland ice sheet 
tom characteristics (Mortensen et al. 2011). Sea ice cover varies from none at all in the outer bays to several months per year in inner fjord branches, where land-fast ice in severe winters may begin to form in November and breaks up in May/June (Jensen \& Rasch 2013). Distances are relatively large, with the inner part of fjord branches located approximately $100 \mathrm{~km}$ from the head of the fjord (Fig. 1). The fjord system is subjected to a tidal range of 3 to $5 \mathrm{~m}$.

During field campaigns in August 2009, 2010 and 2012, we visited a number of sites with historic observations to assess whether eelgrass was still present. Four of the identified eelgrass sites were selected for quantification of shoot density, biomass, annual leaf formation and rhizome elongation and the presence of reproductive shoots and seedlings. Three of these sites, Qugssuk, Ameralik and Kapisillit, are located in inner branches of the Godthåbsfjord system and the fourth is located in the outer part of Kobbefjord (Fig. 1, Table 1). The depth at the time of sampling was corrected for tides and expressed relative to the mean water level using tidal information from Nuuk harbor (www.dmi.dk/fo/groenland/hav/tidevandstabeller-groenland/). Water temperature was measured at the time of sampling. In addition, temperature and photosynthetically active radiation (PAR) were logged every 20 min from August 2012 to September 2013 in Kobbefjord, Ameralik and Kapisillit. Two pairs of HOBO temperature loggers (U22-001, Onset) and submersible planar $2 \pi$ PAR sensors (Odyssey Data Recording) were deployed just above the meadow canopy at ca. $2 \mathrm{~m}$ depth near sampling sites in the 3 areas. To reduce the risk of fouling a copper ring was mounted around the PAR sensor surface (Manov et al. 2004). The PAR sensors were kept in an upright position by centering each of them in a flat sub-surface buoy positioned above the canopy and attached by line to an anchor. Each unit had the HOBO temperature sensor mounted below the Odyssey logger. The Odyssey loggers were calibrated to a HOBO $2 \pi$ PAR smart sensor S-LIA-M003 connected to a S-THB-M002 logger unit. After retrieval the sensors were brought to the laboratory where light recordings were made before and after cleaning the sensor surface in order to estimate light attenuation due to fouling and particle deposition. No fouling was observed on the PAR sensors, but some of them had a thin layer of silt deposited on their surfaces. The data from replicate loggers were then plotted against each other to determine if sensors had been differently shaded by the silt layers. One of the sensors from Ameralik had systematically lower PAR values from April until recovery, and the data from this logger were therefore discarded. Subsequently all signals were calibrated to that of a Walz ULM-500 planar PAR sensor $(2 \pi$, calibrated in March 2013) during measurements of surface incident irradiance (PAR) over a diurnal cycle.

\section{Eelgrass cover, shoot density and biomass}

Eelgrass cover was estimated visually by hydroscope and underwater video (sport QX, 560 TVL 0.1 Lux; www.LH-camera.dk) to give an approximate indication of the fraction of bottom area covered by the eelgrass, reflecting the patchiness of meadows. The camera, which had a built-in GPS, was lowered from a boat to about $1 \mathrm{~m}$ above the seafloor and towed across the sampled meadows. In Kobbefjord, where we only found one small eelgrass meadow with very sparse vegetation, the boundaries of the entire meadow were recorded. Percent cover of eelgrass relative to the seafloor was estimated from point observations haphazardly scattered over the meadows.

Shoot density and biomass of above- and belowground plant parts were measured by harvesting the total biomass using a corer (inner diameter $15 \mathrm{~cm}$ ) which was inserted 15 to $20 \mathrm{~cm}$ into the sediment. At each location, 3 to 5 replicate samples were randomly collected within areas of dense eelgrass vegetation.

Table 1. Zostera marina. Eelgrass sampling sites in the Godthåbsfjord system and general information on the sites. Water depths are tide-corrected relative to the mean water level. Salinity and water temperature were measured on the date of sampling. Eelgrass cover was not determined (nd) in Qugssuk

\begin{tabular}{|lcccc|}
\hline & Kobbefjord & Qugssuk & Ameralik & Kapisillit \\
\hline Coordinates & $64^{\circ} 09^{\prime} \mathrm{N}, 51^{\circ} 33^{\prime} \mathrm{W}$ & $64^{\circ} 45^{\prime} \mathrm{N}, 51^{\circ} 05^{\prime} \mathrm{W}$ & $64^{\circ} 15^{\prime} \mathrm{N}, 51^{\circ} 35^{\prime} \mathrm{W}$ & $64^{\circ} 28^{\prime} \mathrm{N}, 50^{\circ} 13^{\prime} \mathrm{W}$ \\
Sampling date & $14 \mathrm{Aug} 2009$ & $19 \mathrm{Aug} 2010$ & 19 Aug 2009 & 11 Aug 2009 \\
Depth (m) & 2.5 & 2.0 & 3.1 & 3.8 \\
Salinity (psu) & 34 & 17 & 28 & 20 \\
Temperature $\left({ }^{\circ} \mathrm{C}\right)$ & 9.0 & 12.9 & 15.0 & 14.0 \\
Eelgrass cover $(\%)$ & $<10$ & nd & & $80-100$ \\
\hline
\end{tabular}


The content of the corer was put into a mesh bag and washed free of sediment under water. At Kapisillit and Ameralik the shoots were very long (up to $90 \mathrm{~cm}$ ) and occasionally damaged by the corers during sampling. The aboveground biomass from these 2 sites was therefore quantified as the product of shoot density and average leaf shoot weight of 30 to 100 randomly harvested shoots.

In the laboratory, the samples were rinsed of remaining sediment, debris and dead tissues, and epiphytes were removed. The number of shoots was counted to estimate shoot density and frequency of reproductive shoots. The biomass was then separated into shoots (reproductive and vegetative), rhizomes and roots. Shoot length (maximum leaf length) was measured, and the number of leaves per shoot was counted on subsamples of 20 to 30 vegetative shoots taken from all biomass corers harvested. All biomass fractions were rinsed in freshwater, placed separately in paper bags, dried to constant weight at $60^{\circ} \mathrm{C}$ for $24 \mathrm{~h}$ and weighed.

\section{Leaf formation and rhizome elongation}

The annual leaf formation rate was measured by reconstructing past growth from the seasonal pattern of changing rhizome internode lengths, with short internodes being formed in winter and long internodes in summer, and assuming a 1:1 relationship between rhizome internode and leaf formation (Sand-Jensen 1975, Duarte et al. 1994). From each of the studied populations, long, intact rhizomes (6 to 14 replicates) were carefully excavated by the diver from the apical shoot to the oldest portion possible. In the laboratory, the rhizome pieces were rinsed free of sediments and remnants of old leaves were removed. The length of each internode was measured to the nearest millimetre from the apex to the oldest part retrieved. The sequences of internode lengths were filtered for the presence of short-term (running average of 3 internodes) and inter-annual (running average of 11 to 19 internodes, corresponding to $150 \%$ of the expected annual cycle) variability (Short \& Duarte 2001). Subsequently, the annual production was determined as the number of internodes between the 2 consecutive winter minima. For Qugssuk, however, the oldest portion of the retrieved rhizomes was $<18$ mo old, and leaf production was therefore estimated from the number of internodes produced between the 2 summer maxima. Annual rhizome extension was estimated as the length of rhizome pieces between the 2 internodes representing consecutive winter minima.

\section{CNP tissue content}

Carbon and nitrogen content of the dried leaf, rhizome and root material was analysed using an elemental analyser (Robo-Prep-C/N), in line with a mass spectrometer (Tracer mass, Europa Scientific), while phosphorus content was analysed colourimetrically after acid digestion (Koroleff 1983; Danish Standard DS291). Eelgrass shoots from Qugssuk were not analysed for phosphorus content, and only leaf material was analysed for carbon and nitrogen content.

\section{Data analysis}

One-way analysis of variance (ANOVA) with Tukey post hoc multiple range tests was used to analyse for differences among populations, and Bartlett's test was used to check for variance homogeneity. These tests were supplemented with the non-parametric Kruskal-Wallis test, when the demand of variance homogeneity for parametric tests was not met. The relationship between seagrass growth characteristics and latitude was analysed by linear regression. Statistical analyses were performed in Statgraphics (7.0).

\section{RESULTS}

\section{Past and present observations of eelgrass}

The earliest record of eelgrass Zostera marina in Greenland dates back to 1813, but without any mention of the site (Lange 1890). Eelgrass was documented in the Godthåbsfjord system for the first time in 1830 (Lange 1890) and subsequently on a number of occasions in the late 19th century, early-mid-20th century, as well as in 1973 (Rosenvinge 1892, Bendixen 1921, Porsild 1935; herbarium specimens from Greenland Herbarium, Botanical Museum, University of Copenhagen). All historical observations represent meadows located in the protected inner fjord branches, and most of the sites have been revisited over the years (Fig. 1). The populations were separated (10s of kilometres apart) by exposed, deeper and colder fjord sections lined by bedrock. On some occasions flowering shoots were observed, but otherwise the historic observations provided no information on meadow characteristics. We found no documentation for eelgrass further north than the Godthåbsfjord system at $64^{\circ} \mathrm{N}$. Porsild visited Disko Bay $\left(69^{\circ} \mathrm{N}\right)$ in 1931 , but it was specified that he did 
not find eelgrass (Porsild 1935, p. 62). Based on herbarium collections, den Hartog (1970) reported the occurrence of eelgrass in the Disko Bay area (Nugsuak Head), but validation of the original herbarium specimens (C. G. Trapnell 2-7-1928, No. 211, Royal Botanical Gardens Kew) revealed that they were collected at Qugssuk (Kugssuk Head), Godthåbsfjord. The historic information also included an unverified eelgrass site on the southeastern coast of Greenland at $70^{\circ} \mathrm{N}$ (Hartz 1901).

We found all the historic eelgrass sites of the Godthåbfjord system during the summers (August) of 2009 to 2012, except for 2 sites, which we did not visit (Fig. 1) We can, thus, deduce that the present eelgrass populations are 100 to $200 \mathrm{yr}$ or older. In addition, a small eelgrass population on the central south coast of Kobbefjord (Sampling Site 1) was identified recently for the first time (Heilmann pers. comm.), despite its proximity to Nuuk (Fig. 1). Finally, there are other recent but unverified observations of eelgrass meadows as far north as Aassiat $\left(68^{\circ} \mathrm{N}\right.$, observation from plane), south of the Godthåbsfjord system (Ikatoq fjord, $63^{\circ} \mathrm{N}$ ) and around Nanortalik $\left(60^{\circ} \mathrm{N}\right)$ in southern Greenland.

\section{Study sites}

Sampling at Kobbefjord, Ameralik and Kapisillit was conducted in mid-August 2009 and at Qugssuk in mid-August 2010 at water depths of 2.0 to $3.8 \mathrm{~m}$ relative to the mean water level (Fig. 1, Table 1). Salinity varied from 17 to 34 psu, with highest values found in the outer Kobbefjord. Water surface temperatures at the 4 study sites varied at the time of sampling from $9^{\circ} \mathrm{C}$ in Kobbefjord in the outer part of the Godthåbsfjord system to $13-15^{\circ} \mathrm{C}$ in the inner fjord branches. Annual water column temperatures, recorded between August 2012 and September 2013 at 3 of the 4 sites, varied considerably over time, with mean daily temperatures ranging from below zero in winter to $10.1^{\circ} \mathrm{C}$ in Kobbefjord and $12.9^{\circ} \mathrm{C}$ in Ameralik and Kapisillit between July and August (Fig. 2). The largest differences in temperature among sites occurred during the growing season. When comparing the running sum of mean water temperatures across summer months (June to August), the cumulative degree days were much lower in Kobbefjord $\left(569^{\circ} \mathrm{C}\right)$ than in Ameralik $\left(889^{\circ} \mathrm{C}\right)$ and Kapisillit $\left(962^{\circ} \mathrm{C}\right)$. Irradiance (PAR) at $2 \mathrm{~m}$ depth ranged from close to 0 photons $\mathrm{m}^{-2} \mathrm{~d}^{-1}$ during winter to a maximum of 17.6 to 25.0 photons $\mathrm{m}^{-2} \mathrm{~d}^{-1}$ between May and June (Fig. 2). The much
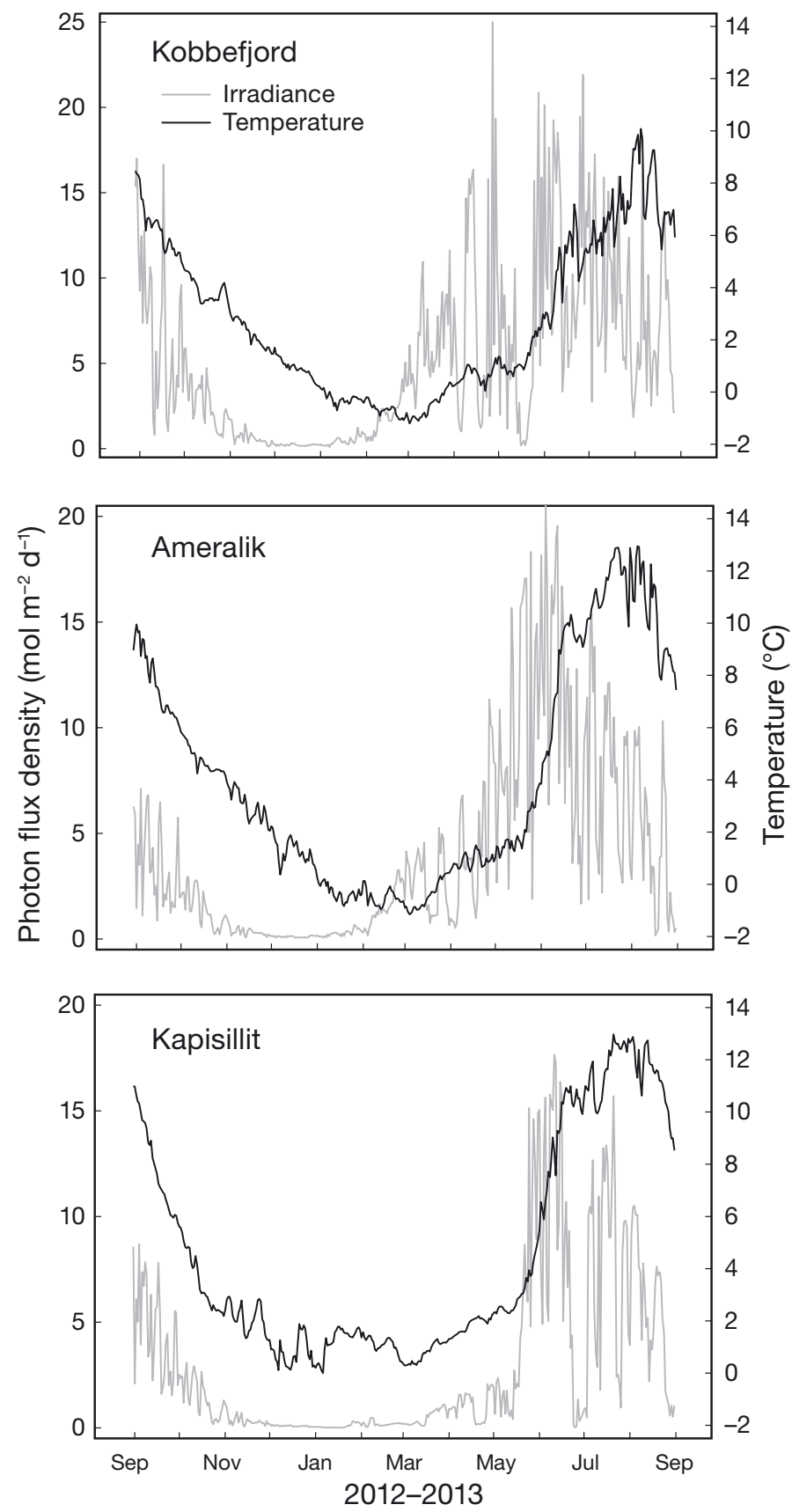

Fig. 2. Seasonal changes in mean daily water temperature and irradiance (PAR) at $2 \mathrm{~m}$ water depth at eelgrass Zostera marina sampling sites in Kobbefjord, Ameralik and Kapisillit

longer winter period of low irradiance $(<0.5$ photons $\mathrm{m}^{-2} \mathrm{~d}^{-1}$ ) in Kapisillit (136 d) compared to the 2 other sites (68 and $90 \mathrm{~d}$ ) implies that ice cover was formed there. Hence, the cumulated annual surface irradiance was much higher in Kobbefjord (1853 photons $\mathrm{m}^{-2} \mathrm{yr}^{-1}$ ) and Ameralik (1470 photons $\mathrm{m}^{-2} \mathrm{yr}^{-1}$ ) than in Kapisillit (1052 photons $\mathrm{m}^{-2} \mathrm{yr}^{-1}$ ). 


\section{Eelgrass cover, biomass and shoot density}

The 3 investigated eelgrass populations located in the inner, relatively warm fjord branches (Qugssuk, Kapisillit, Ameralik; Fig. 1) all represent dense meadows often completely covering the seafloor and in Kapisillit extending down to $\sim 6.5 \mathrm{~m}$ depth (Table 1). The most extensive population was found in Ameralik, where eelgrass formed dense belts of vegetation extending several kilometres along the innermost northern shore. By contrast, eelgrass vegetation in the outer, colder Kobbefjord consisted of a small, patchy meadow covering an area of $60 \times 75 \mathrm{~m}$ at 0.9 to $2.5 \mathrm{~m}$ depth. The vegetation covered approximately $10 \%$ of the seafloor and consisted of patches of varying size and shoot density interrupted by bare areas.

The aboveground biomass differed significantly (ANOVA, $p=0.045$ ) among sites and was higher in the populations growing in the inner, warmer fjord branches of Kapisillit and Ameralik than in the population from Kobbefjord, which was exposed to more light but colder summer temperatures (Fig. 3). Belowground biomass did not differ significantly among sites (Fig. 3; ANOVA, p = 0.099). The total biomass ranged between 193 and $571 \mathrm{~g} \mathrm{DW} \mathrm{m}^{-2}$ across all populations. Shoot density was significantly higher in Kobbefjord (2044 shoots $\mathrm{m}^{-2}$ ) than in populations representing inner-fjord branches (Fig. 3; 871 to 1462 shoots $\mathrm{m}^{-2}$, ANOVA $\mathrm{p}=0.010$ ). Reproductive shoots with initial anthesis were observed in the 3 populations from inner fjord branches of Qugssuk (average: $7 \%$, range: 0 to $28 \%$ ), Ameralik (average: $4 \%$, range: 0 to $10 \%$ ) and Kapisillit (observed outside sample area), but not in Kobbefjord (Fig. 3). No seedlings were observed at the time of sampling. However, reproductive shoots with mature seeds were observed from 27 to 30 August 2012 in Ameralik and Kapisillit, but not in Kobbefjord (not shown).
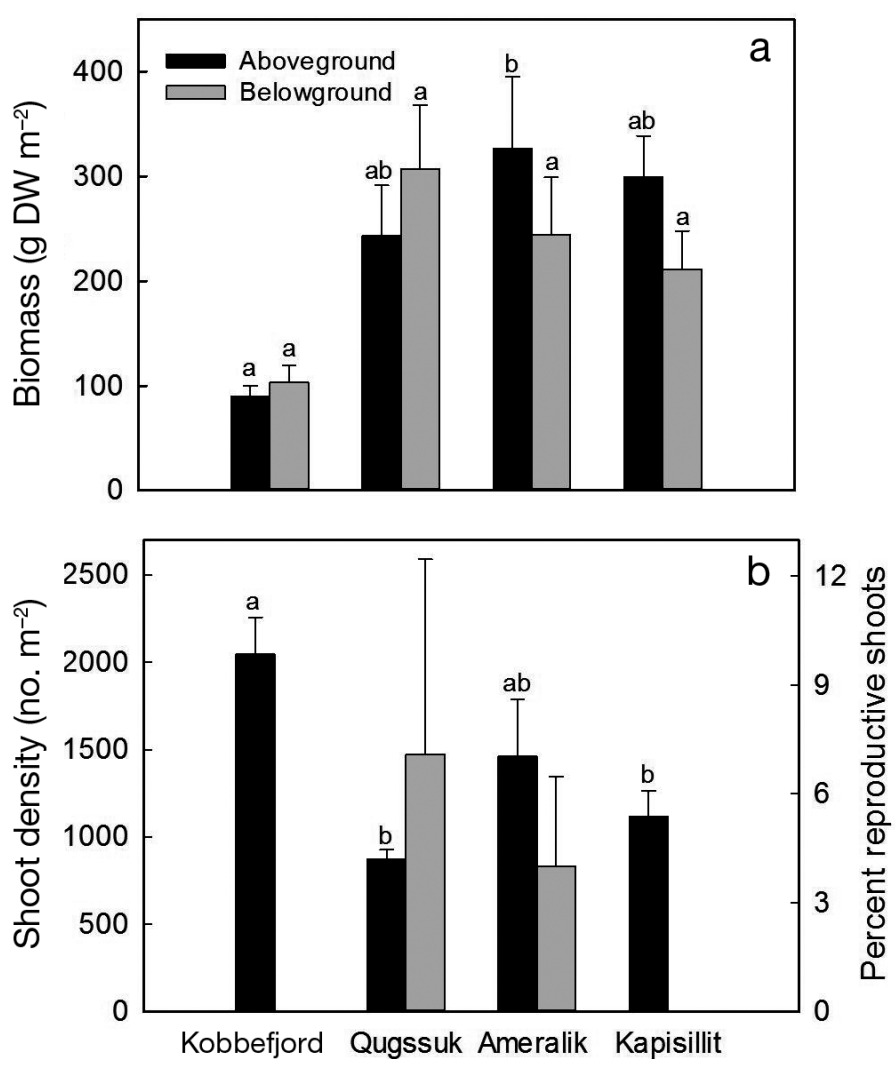

Fig 3. Zostera marina. (a) Eelgrass standing biomass (aboveground and belowground), and (b) shoot density and percentage reproductive shoots of the 4 meadows studied in the Godhåbsfjord system. Different letters indicate statistical differences between populations given by the ANOVA $(\mathrm{p}<0.05)$. Averages $\pm \mathrm{SE}, \mathrm{n}=3-5$

The combination of high aboveground biomass and low shoot density of the populations of inner fjord branches shows that the individual shoots were large (average length: 31 to $56 \mathrm{~cm}$ ), whereas the low aboveground biomass and high shoot density at Kobbefjord reflect a population of small shoots (average length $18 \mathrm{~cm}$; Table 2). The average number of

Table 2. Zostera marina. Eelgrass shoot length and leaf number $(\mathrm{n}=30-40)$, average length of rhizome internodes produced in $1 \mathrm{yr}(\mathrm{n}=9-17)$, leaf formation rate, leaf P/B ratio, and rhizome elongation $(\mathrm{n}=6-13)$ in the 4 sampled populations. Superscripted letters indicate statistical differences between populations given by ANOVA or Kruskal-Wallis (for shoot length and leaf number) analysis. Significance level, $\mathrm{p}<0.001$ for all variables. Average $\pm \mathrm{SE}$

\begin{tabular}{|c|c|c|c|c|}
\hline Variable & Kobbefjord & Qugssuk & Ameralik & Kapisillit \\
\hline Shoot length (cm) & $18.4 \pm 0.9^{\mathrm{a}}$ & $31.2 \pm 4.2^{\mathrm{ab}}$ & $56.0 \pm 4.1^{\mathrm{c}}$ & $46.9 \pm 1.4^{\mathrm{bc}}$ \\
\hline Leaves shoot $^{-1}$ & $4.2 \pm 0.2^{\mathrm{ab}}$ & $4.4 \pm 0.4^{\mathrm{ab}}$ & $3.6 \pm 0.2^{\mathrm{a}}$ & $5.1 \pm 0.2^{\mathrm{b}}$ \\
\hline Rhizome internode length (mm) & $10.4 \pm 0.8^{\mathrm{a}}$ & $17.9 \pm 0.7^{\mathrm{c}}$ & $14.4 \pm 0.7^{\mathrm{b}}$ & $22.1 \pm 1.3^{\mathrm{d}}$ \\
\hline Leaf formation (leaves shoot ${ }^{-1} \mathrm{yr}^{-1}$ ) & $6.9 \pm 0.3^{\mathrm{a}}$ & $10.7 \pm 0.4^{\mathrm{c}}$ & $8.7 \pm 0.2^{\mathrm{b}}$ & $13.1 \pm 0.3^{\mathrm{d}}$ \\
\hline Leaf $P / B$ ratio & 1.7 & 2.4 & 2.4 & 2.6 \\
\hline Rhizome elongation $\left(\mathrm{cm} \mathrm{yr}^{-1}\right.$ ) & $8.2 \pm 0.7^{\mathrm{a}}$ & $17.6 \pm 1.1^{\mathrm{c}}$ & $12.1 \pm 0.6^{\mathrm{b}}$ & $28.8 \pm 2.5^{\mathrm{d}}$ \\
\hline
\end{tabular}


leaves per shoot varied from 3.6 to 5.1 and was significantly lower at Kobbefjord and Ameralik than at the 2 other sites (Kruskal-Wallis test, $\mathrm{p}<0.001$ ).

The analysis of rhizome internodal sequences revealed a clear annual cycle in intermodal lengths and indicated that the harvested rhizomes were at least $2 \mathrm{yr}$ old (Fig. 4). The longest internodes produced varied from $18.5 \mathrm{~mm}$ in Kobbefjord to between 24.9 and $29.0 \mathrm{~mm}$ at the other 3 sites and were typically 3 times longer than the shortest ones produced during winter. Average internode length varied significantly among sites and was lowest in shoots from Kobbefjord and longest at Kapisillit (Table 2).

The number of rhizome internodes between 2 consecutive winter minima suggests that the populations produced 7 to 13 leaves shoot ${ }^{-1} \mathrm{yr}^{-1}$, with significantly (ANOVA, p < 0.001) higher leaf production rates of populations from inner fjord branches as compared to the population from Kobbefjord (Fig. 4, Table 2). Leaf biomass turnover rates, calculated as annual leaf formation divided by the average number of leaves per shoots, were moderate (1.6 to $2.6 \mathrm{yr}^{-1}$; Table 2). Annual rhizome elongation and, thus, the potential for lateral patch growth varied 4fold among populations, with the slowest rates in the Kobbefjord populations $\left(8.2 \mathrm{~cm} \mathrm{yr}^{-1}\right)$ and the fastest in Kapisillit $\left(29 \mathrm{~cm} \mathrm{yr}^{-1}\right)$ (Table 2).

Tissue carbon (C) content of the examined eelgrass populations was similar (ANOVA, p > 0.05) and ranged between 36.1 and $39.6 \%$ DW in leaf tissue and between 27.7 and $35.6 \%$ DW in belowground structures (Fig. 5). The leaf nutrient content ( $\mathrm{N}$ and $\mathrm{P}$ ) varied significantly among sites (ANOVA, $\mathrm{p}=0.001$ to 0.028 ), with higher values in the Kobbefjord population than in the populations from the inner fjord branches (Fig. 5). The leaf $\mathrm{N}$ content varied from 1.35 to $2.33 \%$ DW among populations, whereas the $\mathrm{N}$ content in rhizomes was typically half this level (0.79 to $0.96 \% \mathrm{DW}$ ) and that of root tissue varied from 1.18 to $1.65 \% \mathrm{DW}$. The P content in leaves varied from 0.25 to $0.42 \%$ DW and was equally variable in rhizomes $(0.12$ to $0.55 \% \mathrm{DW})$, whereas the P content of roots $(0.12$ to $0.18 \%$ DW) was similar among sites (Fig. 5). The N:P molar ratio of leaves (12.3 to 13.6) was similar among sites $(p=0.723)$.

\section{Latitude comparison}

The compiled data set represents information on annual maximum leaf biomass from 75 different eelgrass populations and annual leaf formation rates from 23 populations at locations ranging in latitude
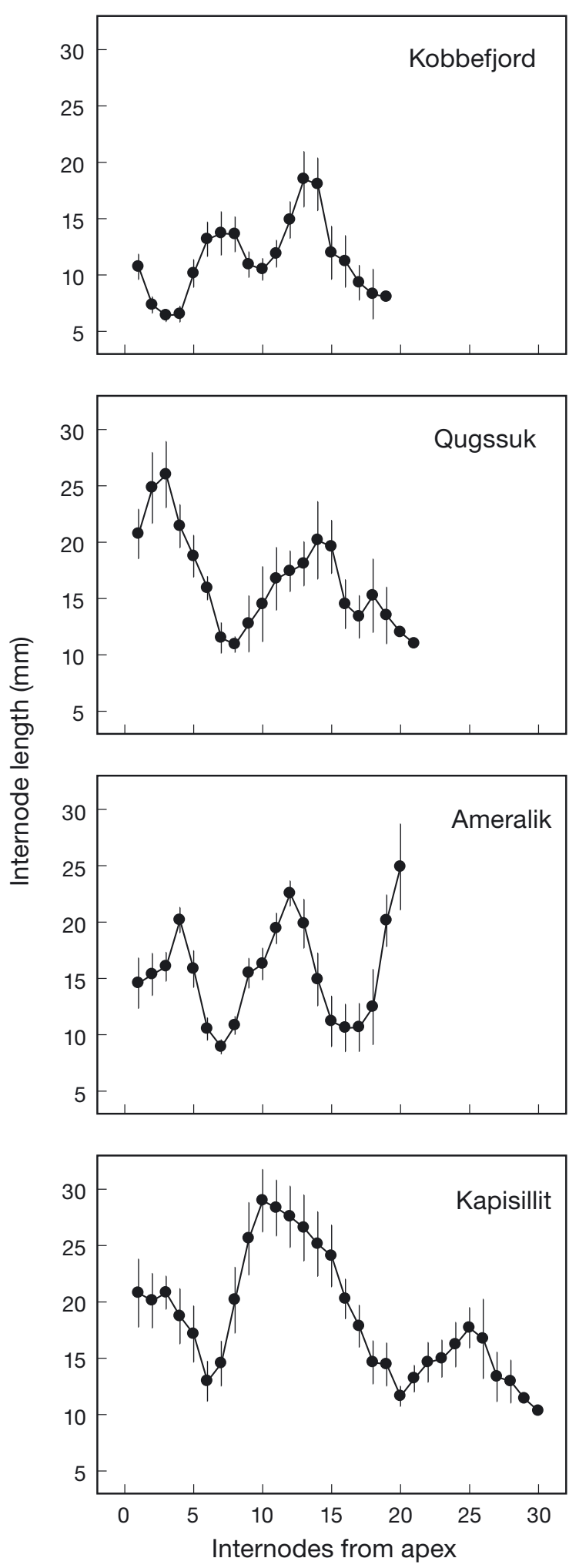

Fig. 4. Zostera marina. Seasonal pattern in internode lengths along eelgrass rhizomes from the youngest internode at time of sampling (August) to the oldest rhizome portions retrieved. Values are averages $( \pm \mathrm{SE})$ of 6 to 13 replicate rhizome pieces 

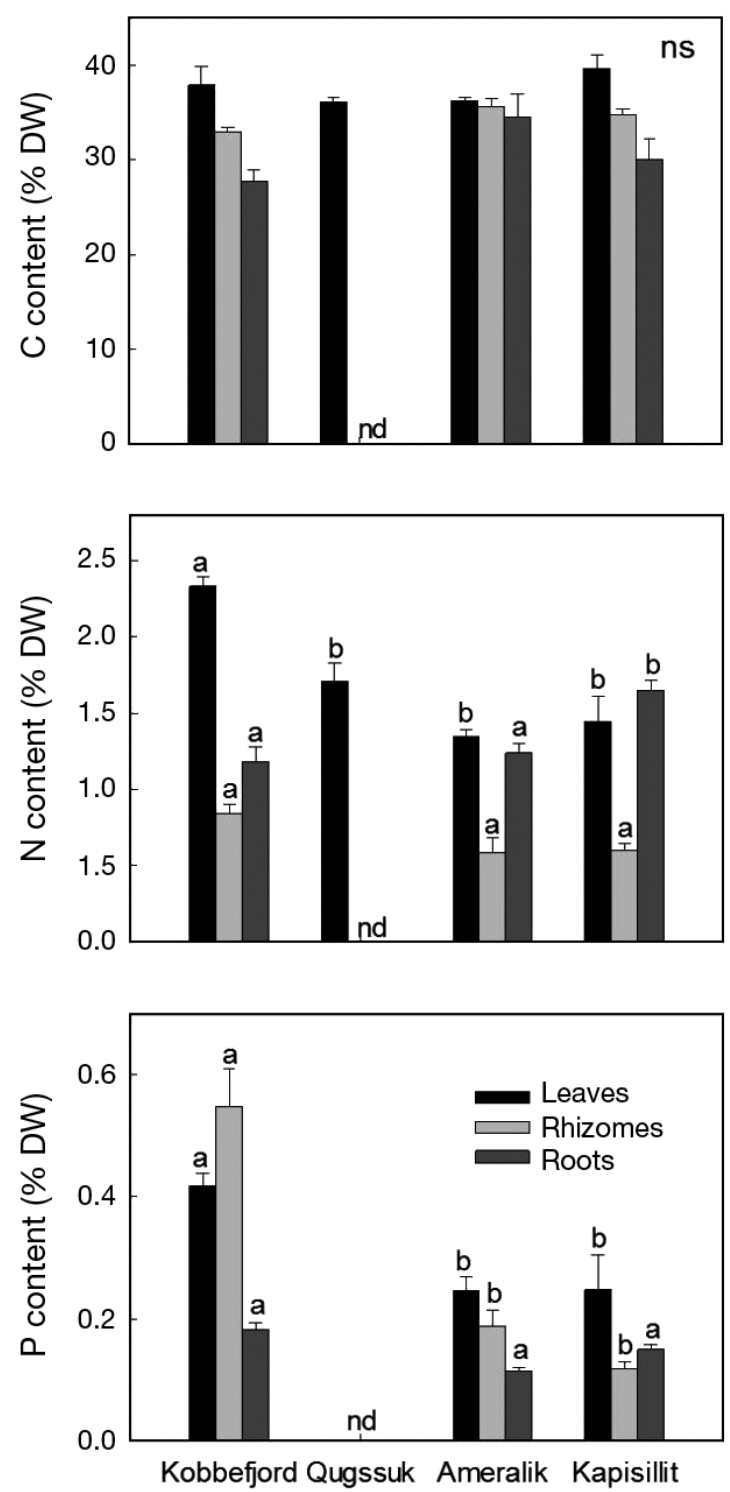

Fig. 5. Zostera marina. Carbon (C), nitrogen (N) and phosphorus (P) content in aboveground and belowground biomass of eelgrass shoots from the 4 studied sites in the Godhåbsfjord system. For shoots from Qugssuk, leaf P content and rhizome/root CNP content were not determined (nd). Different letters indicate statistical differences between populations given by the ANOVA $(p<0.05)$. Averages $\pm S E$, $\mathrm{n}=3$. ns: no significance

from 28.5 to $66.3^{\circ} \mathrm{N}$ (Table 3, Fig. 6). Overall standing leaf biomass values of the Greenland eelgrass populations were comparable to those reported for eelgrass meadows elsewhere in the geographical distribution range, so we identified no latitudinal trend (Fig. 6; linear regression, $\mathrm{R}^{2}<0.01$ ). Likewise, there was no effect of summer air temperature on maximum leaf biomass $\left(R^{2}=0.02\right)$. By contrast, annual leaf formation rates of the Greenland populations were several folds lower than levels reported from lower latitudes and warmer areas. There was a rather clear latitudinal trend, with leaf production rates increasing by on average 0.75 leaves shoot ${ }^{-1} \mathrm{yr}^{-1}$ for every 1 degree of latitude southward $\left(R^{2}=0.57\right.$; Fig. 6$)$. Leaf formation was also significantly related to summer air temperatures and increased by 1.4 leaves $\mathrm{yr}^{-1}$ per $1^{\circ} \mathrm{C}$ increase $\left(\mathrm{R}^{2}=0.57\right.$; Fig. 6$)$.

\section{DISCUSSION}

\section{The northernmost eelgrass populations}

The eelgrass Zostera marina meadows in Godthåbsfjorden at $64^{\circ} \mathrm{N}$ are among the northernmost known eelgrass populations in Greenland, although sporadic and unverified historic observations suggest the occurrence of eelgrass further north on the west coast in the Disko Bay area $\left(69^{\circ} \mathrm{N}\right)$ and on the east coast at $70^{\circ} \mathrm{N}$ (Kap Stewart; Harz 1901). In Godthåbsfjord, all observed eelgrass meadows but one occurred in the inner, warmer and more protected fjord branches, physically separated by 10 s of kilometres (Fig. 1). The meadows were also recorded 100 to $200 \mathrm{yr}$ ago, suggesting that the persistence of these northern populations is not limited by the long, cold winters, where eelgrass in some years lives under a cover of sea ice for up to 7 mo (Jensen \& Rasch 2013), as has also been observed in other studies (McRoy 1969, Lalumière et al. 1994, Naumov 2013). By contrast, the small, sparse eelgrass population in the colder, but usually ice-free waters of Kobbefjord, was observed for the first time in this study. The population is dominated by one large clone (Diekmann \& Serrão 2012), and, given the absence of fertile shoots in our samples, this indicates limited sexual recruitment. Hence, the presence of several small patches (1 to $2 \mathrm{~m}$ ), with a clonal expansion rate of only $8 \mathrm{~cm}$ $\mathrm{yr}^{-1}$, suggests a slow turn-over of patches, but also a slow recovery potential following disturbances (Olesen \& Sand-Jensen 1994b).

\section{Eelgrass performance near the northern distribution limit in Greenland}

The standing leaf biomass of the Greenland meadows in inner fjord branches paralleled that of other populations within the species' distribution range. Hence, climatic differences associated with latitude do not appear to have a strong influence on maximum 
Table 3. Zostera marina. Data from published literature used to assess seasonal leaf biomass maximum $(B)$ and annual leaf formation $(L)$ of eelgrass across the entire geographical distribution range

\begin{tabular}{|c|c|c|c|}
\hline Source & Location & $B$ & $L$ \\
\hline Aioi (1980) & Japan & $\mathrm{x}$ & \\
\hline Bach (1993) & Denmark & $\mathrm{x}$ & \\
\hline Beal et al. (2004) & Maine (USA) & $\mathrm{x}$ & $\mathrm{x}$ \\
\hline Boström et al. (2004) & Finland & $\mathrm{x}$ & \\
\hline Cabello-Pasini et al. (2003) & Mexico & $\mathrm{x}$ & \\
\hline Cebrián et al. (1997) & Spain & $\mathrm{x}$ & \\
\hline Duarte et al. (2002) & Norway & $\mathrm{x}$ & $\mathrm{x}$ \\
\hline Guidetti (2000) & Italy & $\mathrm{x}$ & \\
\hline Hayashida (2000) & Japan & $\mathrm{x}$ & \\
\hline Heck \& Thomas (1984) & Viginia (USA) & $\mathrm{x}$ & \\
\hline Ibarra-Obando (1989) & Mexico & $\mathrm{x}$ & \\
\hline Ibarra-Obando et al. (1997) & Mexico & & $\mathrm{x}$ \\
\hline Jacobs (1979) & France & $\mathrm{x}$ & $\mathrm{x}$ \\
\hline Kentula \& McIntire (1986) & Oregon (USA) & $\mathrm{x}$ & $\mathrm{x}$ \\
\hline Lalumière et al. (1994) & Canada & $\mathrm{x}$ & \\
\hline Lee et al. (2005) & Korea & $\mathrm{x}$ & \\
\hline Lee et al. (2006) & Korea & $\mathrm{x}$ & $\mathrm{x}$ \\
\hline Marbà et al. (1996) & Spain & & $\mathrm{x}$ \\
\hline Marbà unpubl. data & Portugal & & $\mathrm{x}$ \\
\hline McRoy (1970) & Alaska (USA) & $\mathrm{x}$ & \\
\hline McRoy (1974) & Alaska (USA) & $\mathrm{x}$ & \\
\hline Meling-López \& Ibarra-Obando (1999) & Mexico & $\mathrm{x}$ & \\
\hline Mizushima (1985) & Japan & $\mathrm{x}$ & \\
\hline Naumov (2007) & Russia & $\mathrm{x}$ & \\
\hline Nelson \& Waaland (1997) & Washington (USA) & $\mathrm{x}$ & \\
\hline Nienhuis \& de Bree (1980) & The Netherlands & $\mathrm{x}$ & $\mathrm{x}$ \\
\hline Olesen \& Sand-Jensen (1994a) & Denmark & $\mathrm{x}$ & $\mathrm{x}$ \\
\hline Orth \& Heck (1980) & Virginia (USA) & $\mathrm{x}$ & \\
\hline Orth \& Moore (1986) & Virginia (USA) & $\mathrm{x}$ & \\
\hline Pedersen \& Borum (1993) & Denmark & $\mathrm{x}$ & \\
\hline Penhale (1977) & North Carolina (USA) & $\mathrm{x}$ & \\
\hline Poumian-Tapia \& Ibarra-Obando (1999) & Mexico & $\mathrm{x}$ & \\
\hline Robertson \& Mann (1984) & Canada & $\mathrm{x}$ & \\
\hline Roman \& Able (1988) & Massachusetts (USA) & $\mathrm{x}$ & $\mathrm{x}$ \\
\hline Sand-Jensen (1975) & Denmark & $\mathrm{x}$ & $\mathrm{x}$ \\
\hline Sfriso \& Ghetti (1998) & Italy & $\mathrm{x}$ & $\mathrm{x}$ \\
\hline Taniguchi \& Yamada (1979) & Japan & $\mathrm{x}$ & \\
\hline Thom (1990) & Washington (USA) & $\mathrm{x}$ & \\
\hline Thormar unpubl. data & Norway & $\mathrm{x}$ & $\mathrm{x}$ \\
\hline Thorne-Miller et al. (1983) & Rhode Island (USA) & $\mathrm{x}$ & \\
\hline van Lent \& Verschuure (1994) & The Netherlands & $\mathrm{x}$ & \\
\hline Vaughan (1982) in Roman \& Able (1988) & New Jersey (USA) & & $\mathrm{x}$ \\
\hline Watanabe et al. (2005) & Japan & $\mathrm{x}$ & $\mathrm{x}$ \\
\hline Wetzel \& Penhale (1983) & Virginia (USA) & $\mathrm{x}$ & \\
\hline Wium-Andersen \& Borum (1984) & Denmark & $\mathrm{x}$ & $\mathrm{x}$ \\
\hline
\end{tabular}

strong relationship between summer air temperature and annual leaf production suggests that temperature plays a major role in controlling the annual biomass production. This is also suggested by the particularly low leaf production ( 7 leaves $\mathrm{yr}^{-1}$ ) in the Kobbefjord population, which generally is ice-free year round but experiences summer water temperatures below $10^{\circ} \mathrm{C}$, compared to a production of 9 to 13 leaves $\mathrm{yr}^{-1}$ in populations of the warmer $\left(13\right.$ to $\left.15^{\circ} \mathrm{C}\right)$ inner branches of the Godthåbsfjord, which often are ice-covered in winter. Nutrient limitation is also a potential factor restricting growth, but tissue concentrations in plants from Kobbefjord were generally higher than in plants from the inner fjord branches. The low leaf production of Greenland populations combined with a relatively high standing leaf biomass suggest a slower biomass turnover. A similar latitudinal pattern of increasing biomass turnover from north to south has previously been described in a comparison across seagrass species (Duarte 1989). The low rates of leaf turnover in the Greenland populations corresponded to a mean leaf lifespan of 140 to 220 d as compared with a mean value of $32.7 \mathrm{~d}$ in temperate populations (Duarte 1991). The long leaf lifespan of these northern eelgrass populations indicates that they maintain metabolically active leaves during winter, as has been observed in other subarctic eelgrass populations and in freshwater macrophytes under winter ice cover (McRoy 1969, Boylen \& Sheldon 1976).

Not only the vegetative growth, but also the sexual reproduction of the

leaf biomass achieved during the active growth period, although the period when peak biomass is reached can be expected to occur later in the growing season than at lower latitudes (Duarte 1989, Clausen et al. 2014). In contrast, the annual leaf formation rate was closely coupled to large-scale differences in climate across latitudes, and was 4-fold lower in the Greenland populations than further south. Although irradiance and temperature probably interact in the observed effect of latitude on leaf production, the studied eelgrass populations seemed to be constrained by the colder climate in Greenland. Reproductive shoots were commonly observed in populations from the inner warmest fjord branches, but flower development was initiated much later (midAugust) than in most temperate populations (February to June; Phillips et al. 1983, Silberhorn et al. 1983). The developmental sequence from flowering to seed maturation requires 1 to 2 mo (de Cock 1980) and possibly longer in cold environments, where low 

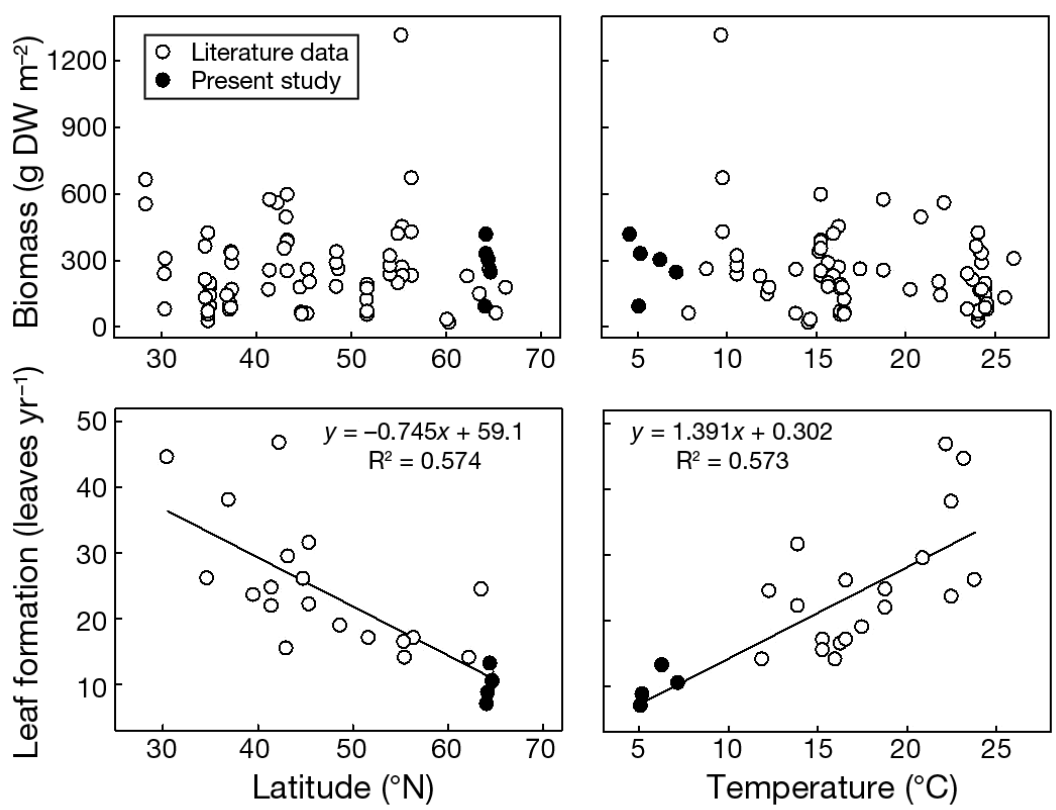

Fig. 6. Zostera marina. Eelgrass leaf biomass and annual leaf formation rate as functions of latitude across the geographical distribution range (left panels) and of mean summer (June to August) air temperature (right panels). Closed symbols: Greenland populations (this study; Table 1); open symbols: data compiled from the literature (Table 3 )

rates of metabolism determine the growth rate, as well as the time required for completion of the reproductive cycle (Brown et al. 2004). Nevertheless, viable seeds, as tested in laboratory germination trials, were found in late August 2012 following an unusually warm July (monthly mean air temperature: $10.4^{\circ} \mathrm{C}$ ) compared to previous years $\left(7.9\right.$ to $\left.8.0^{\circ} \mathrm{C}\right)$ (authors' unpubl. data; www.dmi.dk/groenland/ arkiver/vejrarkiv). Also, Diekmann \& Serrão (2012) recorded relatively high clonal diversity in populations from the inner fjord branches of Ameralik and Kapisillit, which suggests that past recruitment events from seeds have occurred. It is likely that seed development fails to complete in years characterized by a short growing season, with a low number of days in which water temperatures exceed the minimum range of 10 to $15^{\circ} \mathrm{C}$ reported for seed ripening in temperate populations (Jacobs \& Pierson 1981), and we speculate that the outer, colder part of the Godthåbsfjord system represents the minimum temperature range at which sexual reproduction in these northern populations can occur (Fig. 2).

\section{Greenland eelgrass in a warmer future}

The marked influence of climatic conditions on eelgrass leaf production across the entire distributional range suggests that warming may stimulate biomass production of the current populations in Greenland. Air temperature in the region has shown an increasing trend of $\sim 2^{\circ} \mathrm{C}$ (annual mean) over the past $30 \mathrm{yr}$, following a cooling period in the 1970s (Cappelen \& Vinther 2014), and with a further 2 to $3^{\circ} \mathrm{C}$ of warming anticipated for the end of the 21th century (Stendel et al. 2008). Since this is the first quantitative study of eelgrass in Greenland, it is not known whether recent warming has already affected eelgrass growth and reproduction. The arctic marine biota has only been explored to a limited extent, but there are examples of marine macroalgae showing marked increases in coverage (Kortsch et al. 2012) and production (Krause-Jensen et al. 2012) over the latest decades, as a response to warming and reductions in sea ice cover. The existing lack of long timeseries, especially for the Arctic, limits the potential to assess responses to climate change (Wassmann et al. 2011). One useful approach to overcome this problem is extrapolation of temporal dynamics from spatial variation. Latitudinal studies of relationships between, e.g., temperature, sea ice cover and the performance of the biota have proved useful for addressing the effects of warming through time-for-space substitution (Fukami \& Wardle 2005, Blicher et al. 2007, Sejr et al. 2009, Krause-Jensen et al. 2012). Similarly, our analysis of eelgrass performance across the species' latitudinal range may provide an indication of how leaf production responds to warming. Hence, eelgrass production is predicted to increase by 1.4 leaves shoot ${ }^{-1} \mathrm{yr}^{-1}$ per degree Celsius increase in air temperature, as indicated by the slope estimate of the linear regression in Fig. 6. In addition to higher production in a warmer future, it is expected that the distribution of eelgrass will move northward. Range shifts have already been observed among arctic terrestrial species (Serreze et al. 2000, Post et al. 2009), although recent studies indicate that the current northern distribution limit in Greenland is strongly shaped by dispersal limitation and other disequilibrium dynamics (e.g. unsuitable soil), resulting in migration lags of 100 s to 1000 s of years (Normand et al. 2013). The floating reproductive shoots of eelgrass are capable of long-distance dispersal in marine systems (up to $150 \mathrm{~km}$; Kendrick et al. 2012), 
which enables them to colonize distant habitats. Also, the possibility of successful dispersal by herbivores was recently suggested (Sumoski \& Orth 2012). On the other hand, factors such as unfavorable local current regimes, a coastline dominated by rocky shores, lack of shallow soft-bottom habitats and mechanical stress from ice scour are likely to restrain a prompt northward migration. In addition to seed dispersal, seedling establishment is generally regarded as a key constraint on recruitment (Moore \& Short 2006) and could also be a major determinant of the speed and extent of future expansion.

Most studies on the effects of increased temperature on eelgrass and other seagrass species have been conducted near the southern distribution limit or centrally in the distribution range where eelgrass is increasingly stressed by high summer temperatures proposed to be the result of global climate change (e.g. Reusch et al. 2005, Marbà \& Duarte 2010, Moore et al. 2012, Raun \& Borum 2013). By contrast there has been little focus on the effects of warming on northern eelgrass populations. This study provides evidence that eelgrass in subarctic Greenland has the capacity to develop high abundances, and we speculate that increasing temperatures are likely to stimulate the annual production and reproductive success within current meadows, but also to expand the general range along the west coast of Greenland. Given their key role in nearshore ecosystems and their sensitivity to water quality and stressors, such as temperature, eelgrass meadows represent potential biological sentinels of climate change near the northern limit of the species' distribution.

Acknowledgements. This work was funded by the European Union's Seventh Framework Programme, grant agreement No. 226248, Arctic Tipping Points (ATP), and by the Aarhus University Research Foundation's (E-2009-FLS-5-41), Ecology of the Inter-tidal Zone in Greenland (ECO-TIDE). We are grateful to Peder Bøcher, Department of Bioscience, for providing air temperature data; and to Martin Blicher, Flemming Heinrich and Lars Heilmann, Greenland Institute of Natural Resources; Bent Heiselberg, Nuuk, and Kurt Pedersen, Piareersafik, Greenland, for providing recent observations of $Z$. marina populations in Greenland.

\section{LITERATURE CITED}

Aioi K (1980) Seasonal change in the standing crop of eelgrass (Zostera marina L.) in Odawa Bay, Central Japan. Aquat Bot 8:343-354

Bach HK (1993) A dynamic model describing the seasonal variations in growth and the distribution of eelgrass (Zostera marina L.). I. Model theory. Ecol Modell 65:31-50
Beal BF, Vadas RL Sr, Wright WA, Nickl S (2004) Annual aboveground biomass and productivity estimates for intertidal eelgrass (Zostera marina L.) in Cobscook Bay, Maine. Northeast Nat 11:197-224

Bendixen O (1921) Godthaab Distrikt. Grønland i Tohundredeaaret for Hans Egedes Landing. In: Amdrup GC, Bobé L, Jensen ADS, Steensby HP (eds) Meddelelser om Grønland. Kommissionen for ledelsen af de geologiske og geografiske undersøgelser i Grønland LXI, Vol. II. Bianco Lunos Bogtrykkeri, Copenhagen, p 176-269

Berger VY (2011) Production of the eel grass Zostera marina Linnaeus, 1753 in the White Sea. Russ J Mar Biol 37: 371-375

Bergmann N, Winters G, Rauch G, Eizaguirre C and others (2010) Population-specificity of heat stress gene induction in northern and southern eelgrass Zostera marina populations under simulated global warming. Mol Ecol 19:2870-2883

Blicher M, Rysgaard S, Sejr MK (2007) Growth and production of the sea urchin, Strongylocentrotus droebachiensis in a high-Arctic fjord, and growth along a climate gradient (64 to $77^{\circ}$ N). Mar Ecol Prog Ser 341:89-102

Boström C, Roos C, Rönnberg O (2004) Shoot morphometry and production dynamics of eelgrass in the northern Baltic Sea. Aquat Bot 79:145-161

Boström C, Baden S, Bockelmann AC, Dromph K and others (2014) Distribution, structure and function of Nordic seagrass ecosystems: implications for coastal management and conservation. Aquat Conserv 24:410-434

> Boylen CW, Sheldon RB (1976) Submergent macrophytes: growth under winter ice cover. Science 194:841-842

Brown JH, Gillooly JF, Allen AP, Savage VM, West GB (2004) Toward a metabolic theory of ecology. Ecology 85: 1771-1789

Cabello-Pasini A, Muñiz-Salazar R, Ward DH (2003) Annual variations of biomass and photosynthesis in Zostera marina at its southern end of distribution in the North Pacific. Aquat Bot 76:31-47

Cappelen J, Vinther BM (2014) SW Greenland temperature data 1784-2013. Technical Report 14-06, DMI, Copenhagen

> Cebrián J, Duarte CM, Marbà N, Enríquez S (1997) The magnitude and fate of the production of four co-ocurring western Mediterranean seagrass species. Mar Ecol Prog Ser 155:29-44

Clausen KK, Krause-Jensen D, Olesen B, Marbà N (2014) Seasonality of eelgrass biomass across gradients in temperature and latitude. Mar Ecol Prog Ser 506:71-85

Cottam C, Munro DA (1954) Eelgrass status and environmental relations. J Wildl Manag 18:449-460

de Cock AWAM (1980) Flowering, pollination and fruiting in Zostera marina L. Aquat Bot 9:201-220

den Hartog C (1970) The seagrasses of the world. North Holland Publ., Amsterdam

> Diekmann OE, Serrão EA (2012) Range-edge genetic diversity: locally poor extant southern patches maintain a regionally diverse hotspot in the seagrass Zostera marina. Mol Ecol 21:1647-1657

Dring MJ (1992) The biology of marine plants. Cambridge University Press, Cambridge

> Duarte CM (1989) Temporal biomass variability and production/biomass relationships of seagrass communities. Mar Ecol Prog Ser 51:269-276

> Duarte CM (1991) Allometric scaling of seagrass form and productivity. Mar Ecol Prog Ser 77:289-300 
Duarte CM, Marbà N, Agawin N, Cebrián J and others (1994) Reconstruction of seagrass dynamics: age determinations and associated tools for the seagrass ecologist. Mar Ecol Prog Ser 107:195-209

> Duarte CM, Martínez C, Barrón C (2002) Biomass, production and rhizome growth near the northern limit of seagrass (Zostera marina) distribution. Aquat Bot 72:183-189

> Fukami T, Wardle DA (2005) Long-term ecological dynamics: reciprocal insights from natural and anthropogenic gradients. Proc R Soc Lond B Biol Sci 272:2105-2115

Green EP, Short FP (eds) (2003) World atlas of seagrasses: present status and future conservation. UNEP, University of California Press, Berkeley, CA

Guidetti P (2000) Temporal dynamics of Zostera marina L. off the Lagoon of Grado (northern Adriatic Sea, Italy). Bot Mar 43:541-546

Hartz N (1901) Den østgrønlandske expedition 1900. Skibsexpeditionen fra Kap Dalton til Kong Oscars Fjord. Geografisk Tidsskrift 16:133-142

> Hayashida F (2000) Vertical distribution and seasonal variation of eelgrass beds in Iwachi Bay, Izu Peninsula, Japan. Hydrobiologia 428:179-185

$>$ Heck KL, Thomas TA (1984) The nursery role of seagrass meadows in the upper and lower reaches of the Chesapeake Bay. Estuaries 7:70-92

Ibarra-Obando SE (1989) Las praderas de pastos marinos del Pacifico Mexicano con enfasis en Zostera marina Linneo. In: De la Rosa-Velez J, Gonzalez-Farias F (eds) Temas de Oceanografia Biológica en Mexico. Universidad Autónoma de Baja California, Ensenada, p 1-20

> Ibarra-Obando SE, Boudouresque CF, Roux M (1997) Leaf dynamics and production of a Zostera marina bed near its southern distributional limit. Aquat Bot 58:99-112

IPCC (Intergovernmental Panel on Climate Change) (2007) Fourth assessment report. Climate Change 2007. Available at: www.ipcc.ch/ipccreports/assessments-reports.htm

$>$ Jacobs RPWM (1979) Distribution and aspects of the production and biomass of eelgrass, Zostera marina L., at Roscoff, France. Aquat Bot 7:151-172

> Jacobs RPWM (1984) Biomass potential of eelgrass (Zostera marina L.). Crit Rev Plant Sci 2:49-80

> Jacobs RPWM, Pierson ES (1981) Phenology of reproductive shoots of eelgrass, Zostera marina L., at Roscoff (France). Aquat Bot 10:45-60

> Jarvis JC, Moore KA, Kenworthy WJ (2012) Characterization and ecological implication of eelgrass life history strategies near the species' southern limit in the western North Atlantic. Mar Ecol Prog Ser 444:43-56

Jensen LM, Rasch M (eds) (2013) Nuuk ecological research operations, 6st annual report, 2012. Aarhus University, DCE-Danish Centre for Environment and Energy, Roskilde

> Jørgensen NM, Bekkby T (2013) Historical and present distribution of Zostera marina in the high north (Troms County, northern Norway)-and a decline over the last century. Bot Mar 56:425-430

Kendrick GA, Waycott M, Carruthers TJB, Cambridge ML and others (2012) The central role of dispersal in the maintenance and persistence of seagrass populations. Bioscience 62:56-65

> Kentula ME, McIntire CD (1986) The autecology and production dynamics of eelgrass (Zostera marina L.) in Netarts Bay, Oregon. Estuaries 9:188-199

Koroleff F (1983) Determination of phosphorus. In: Grashoff K, Erhard M, Kremling K (eds) Methods of seawater analysis, 2nd edn. Verlag Chemie, Weinheim, p 125-135

Kortsch S, Primicerio R, Beuchel F, Renaud PE, Rodrigues J, Lønne OJ, Gulliksen B (2012) Climate-driven regime shifts in Arctic marine benthos. Proc Natl Acad Sci USA 109:14052-14057

Krause-Jensen D, Marbà N, Olesen B, Sejr MK and others (2012) Seasonal sea ice cover as principal driver of spatial and temporal variation in depth extension and annual production of kelp in Greenland. Glob Change Biol 18:2981-2994

Lalumière R, Messier D, Fournier JJ, McRoy CP (1994) Eelgrass meadows in a low arctic environment, the northeast coast of James Bay, Québec. Aquat Bot 47:303-315

Lange J (1890) Oversigt over Grønlands flora. Meddelelser om Grønland. Kommissionen for ledelsen af de geologiske og geografiske undersøgelser i Grønland, Vol 3. Bianco Lunos Kgl-Hof Bogtrykkeri, Copenhagen

> Lee KS, Park SR, Kim JB (2005) Production dynamics of the eelgrass, Zostera marina in two bay systems on the south coast of the Korean peninsula. Mar Biol 147:1091-1108

Lee SY, Kim JB, Lee SM (2006) Temporal dynamics of subtidal Zostera marina and intertidal Zostera japonica on the southern coast of Korea. Mar Ecol (Berl) 27:133-144

Manov DV, Chang GC, Dickey TD (2004) Methods for reducing biofouling of moored optical sensors. J Atmos Ocean Technol 21:958-968

> Marbà N, Duarte CM (2010) Mediterranean warming triggers seagrass (Posidonia oceanica) shoot mortality. Glob Change Biol 16:2366-2375

> Marbà N, Cebrián J, Enríquez S, Duarte CM (1996) Growth patterns of western Mediterranean seagrasses: speciesspecific responses to seasonal forcing. Mar Ecol Prog Ser 133:203-215

McGlathery KJ, Reynolds LK, Cole LW, Orth RJ, Marion SR, Schwarzschild A (2012) Recovery trajectories during state change from bare sediment to eelgrass dominance. Mar Ecol Prog Ser 448:209-221

McQuaid CD, Branch GM (1984) Influence of sea temperature, substratum and wave exposure on rocky intertidal communities: an analysis of faunal and floral biomass. Mar Ecol Prog Ser 19:145-151

McRoy CP (1968) The distribution and biogeography of eelgrass in Alaska. Pac Sci 22:507-513

McRoy CP (1969) Eelgrass under arctic winter ice. Nature 224:818-819

McRoy CP (1970) Standing stocks and other features of eelgrass (Zostera marina) populations on the coast of Alaska. J Fish Res Board Can 27:1811-1821

McRoy CP (1974) Seagrass productivity: carbon uptake experiments in eelgrass, Zostera marina. Aquaculture 4: 131-137

Meling-López AE, Ibarra-Obando SE (1999) Annual life cycles of two Zostera marina L. populations in the Gulf of California: contrasts in seasonality and reproductive effort. Aquat Bot 65:59-69

Mizushima T (1985) Seasonal changes in standing crop and production of eelgrass (Zostera marina Linné) in Notsuke Bay, eastern Hokkaido. Sci Rep Hokkaido Fish Exp Stn 27:111-118

> Moore KA, Jarvis JC (2008) Environmental factors affecting recent summertime eelgrass diebacks in the lower Chesapeake Bay: implications for long-term persistence. J Coast Res 55:135-147

Moore KA, Short FT (2006) Zostera: biology, ecology, and management. In: Larkum AWD, Orth RJ, Duarte CM 
(eds) Seagrasses: biology, ecology, and conservation. Springer, Dordrecht, p 361-386

- Moore KA, Shields EC, Parrish DB, Orth RJ (2012) Eelgrass survival in two contrasting systems: role of turbidity and summer water temperatures. Mar Ecol Prog Ser 448: $247-258$

Moore KA, Shields EC, Parrish DB (2014) Impact of varying estuarine temperature and light conditions on Zostera marina (eelgrass) and its interaction with Ruppia maritima (widgeongrass). Estuaries Coasts 37:20-30

Mortensen J, Lennert K, Bendtsen J, Rysgaard S (2011) Heat sources for glacial melt in a sub-Arctic fjord (Godthåbsfjord) in contact with the Greenland Ice Sheet. J Geophys Res 116:C01013. doi:10.1029/2010JC006528

> Müller R, Laepple T, Bartsch I, Wiencke C (2009) Impact of oceanic warming on the distribution of seaweeds in polar and cold-temperate waters. Bot Mar 52:617-638

Naumov AD (2007) Long-term investigations of the littoral benthos of the White Sea in the Chupa Guba (Kandalaksha Bay): seasonal and long-term dynamics of the biomass of the eelgrass Zostera marina. Complex investigations of processes, characteristics and resources of Russian Seas of the North European Basin 2. Kola Science Center, RAS, Apatity, p 493-502 (in Russian)

$>$ Naumov AD (2013) Long-term fluctuations of soft-bottom intertidal community structure affected by ice cover at two small sea bights in the Chupa Inlet (Kandalaksha Bay) of the White Sea. Hydrobiologia 706:159-173

- Nejrup LB, Pedersen MF (2008) Effects of salinity and water temperature on the ecological performance of Zostera marina. Aquat Bot 88:239-246

> Nelson TA, Waaland JR (1997) Seasonality of eelgrass, epiphyte, and grazer biomass and productivity in subtidal eelgrass meadows subjected to moderate tidal amplitude. Aquat Bot 56:51-74

- Nienhuis PH, de Bree BHH (1980) Production and growth dynamics of eelgrass (Zostera marina) in brackish lake Grevelingen (The Netherlands). Neth J Sea Res 14: 102-118

> Normand S, Randin C, Ohlemüller R, Bay C and others (2013) A greener Greenland? Climatic potential and long-term constraints on the future expansion of trees and shrubs across a large Arctic region. Philos Trans $\mathrm{R}$ Soc Lond B 368:20120479

Olesen B, Sand-Jensen K (1993) Seasonal acclimatization of eelgrass Zostera marina growth to light. Mar Ecol Prog Ser 94:91-99

Olesen B, Sand-Jensen K (1994a) Demography of shallow eelgrass (Zostera marina) populations - shoot dynamics and biomass development. J Ecol 82:379-390

- Olesen B, Sand-Jensen K (1994b) Patch dynamics of eelgrass Zostera marina. Mar Ecol Prog Ser 106:147-156

Olsen JL, Coyer JA, Stam WT, Moy FE, Christie H, Jørgensen NM (2013) Eelgrass Zostera marina populations in northern Norwegian fjords are genetically isolated and diverse. Mar Ecol Prog Ser 486:121-132

Orth RJ, Heck KL Jr (1980) Structural components of eelgrass (Zostera marina) meadows in the Lower Chesapeake Bay - Fishes. Estuaries 3:278-288

Orth RJ, Moore KA (1986) Seasonal and year to year variations in the growth of Zostera marina L. (eelgrass) in the lower Chesapeake Bay. Aquat Bot 24:335-341

Ostenfeld CH (1927) Meeresgräser II - Marine Potamogetonaceae, Heft 4, Karte 31-40. In: Diels L, Samuelsson G (eds) Die Pflanzenareale. Sammlung kartographischer
Darstellungen von Verbreitungsbezirken der lebenden und fossilen Pflanzen-Familien, -Gattungen und -Arten. Gustav Fischer Verlag, Jena

Pedersen MF, Borum J (1993) An annual nitrogen budget for a seagrass Zostera marina population. Mar Ecol Prog Ser 101:169-177

Penhale PA (1977) Macrophyte epiphyte biomass and productivity in an eelgrass (Zostera marina L.) community. J Exp Mar Biol Ecol 26:211-224

> Phillips RC, Backman TW (1983) Phenology and reproductive biology of eelgrass (Zostera marina L.) at Bahia Kino, Sea of Cortez, Mexico. Aquat Bot 17:85-90

> Phillips RC, McMillan C, Bridges KW (1983) Phenology of eelgrass, Zostera marina L., along latitudinal gradients in North America. Aquat Bot 15:145-156

Porsild AE (1932) Notes on the occurrence of Zostera and Zannichellia in arctic North America. Rhodora 34:90-94

Porsild MP (1935) Stray contributions to the flora of Greenland. VI-XII. Medd Gronl 93:1-94

> Post E, Forchhammer MC, Bret-Harte MS, Callaghan TV and others (2009) Ecological dynamics across the Arctic associated with recent climate change. Science 325: 1355-1358

> Poumian-Tapia M, Ibarra-Obando SE (1999) Demography and biomass of the seagrass Zostera marina in a Mexican coastal lagoon. Estuaries 22:837-847

Raun AL, Borum J (2013) Combined impact of water column oxygen and temperature on internal oxygen status and growth of Zostera marina seedlings and adult shoots. J Exp Mar Biol Ecol 441:16-22

> Reusch TBH, Ehlers A, Hämmerli A, Worm B (2005) Ecosystem recovery after climatic extremes enhanced by genotypic diversity. Proc Natl Acad Sci USA 102:2826-2831

Riis T, Christoffersen KS, Baatrup-Pedersen A (2014) Effects of warming on annual production and nutrient-use efficiency of aquatic mosses in a high Arctic lake. Freshw Biol 59:1622-1632

> Robertson AI, Mann KH (1984) Disturbance by ice and lifehistory adaptations of the seagrass Zostera marina. Mar Biol 80:131-141

Roman CT, Able DW (1988) Production ecology of eelgrass (Zostera marina L.) in a Cape Cod salt marsh-estuarine system, Massachusetts. Aquat Bot 32:353-363

Rosenvinge LK (1892) Andet tillæg til Grønlands Fanerogamer og Karsporeplanter. Medd Gronl 3:645-749

Sand-Jensen K (1975) Biomass, net production and growth dynamics in an eelgrass (Zostera marina L.) population in Vellerup Vig, Denmark. Ophelia 14:185-201

Santamaría-Gallegos NA, Sánchez-Lizaso JL, Félix-Pico EF (2000) Phenology and growth cycle of annual subtidal eelgrass in a subtropical locality. Aquat Bot 66: 329-339

Sejr M, Blicher M, Rysgaard S (2009) Spatial and temporal variation in sea ice cover influence annual growth of the Arctic cockle Clinocardium ciliatum in Greenland. Mar Ecol Prog Ser 389:149-158

Serreze MC, Walsh JE, Chapin FS III, Osterkamp T and others (2000) Observational evidence of recent change in the northern high-latitude environment. Clim Change 46:159-207

Setchell WA (1929) Morphological and phonological notes on Zostera marina L. Univ Calif Publ Bot 14:389-452

Sfriso A, Ghetti PF (1998) Seasonal variation in biomass, morphometric parameters and production of seagrasses in the lagoon of Venice. Aquat Bot 61:207-223 
Short FT, Duarte CM (2001) Methods for the measurement of seagrass growth and production. In: Short FT, Coles RG (eds) Global seagrass research methods. Elsevier, Amsterdam, p 155-182

Silberhorn GM, Orth RJ, Moore KA (1983) Anthesis and seed production in Zostera marina L. (eelgrass) from the Chesapeake Bay. Aquat Bot 15:133-144

Stendel M, Christensen JH, Petersen D (2008) Arctic climate and climate change with a focus on Greenland. Adv Ecol Res 40:13-43

Sumoski SE, Orth RJ (2012) Biotic dispersal in eelgrass Zostera marina. Mar Ecol Prog Ser 471:1-10

Taniguchi K, Yamada Y (1979) Vertical distribution and natural life history of Zostera marina Linné and some other species of seagrass in Iida Bay of the Noto Peninsula on the Honshu, Japan Sea coast. Bull Jpn Sea Reg Fish Res Lab 30:111-122

Thayer GA, Kenworthy WJ, Fonseca KS (1984) The ecology of eelgrass meadows of the Atlantic coast: a community profile. FWS/OBS 84/02, US Department of the Fish and Wildlife Service, www.nwrc.usgs.gov/techrpt/84-02.pdf

Thom RM (1990) Spatial and temporal patterns in plant standing stock and primary production in a temperate seagrass system. Bot Mar 33:497-510

Thorne-Miller B, Harlin MM, Thursby GB, Brady-Campbell MM, Dworetzky BA (1983) Variations in the distribution and biomass of submerged macrophytes in five coastal lagoons in Rhode Island, USA Bot Mar 26:231-242

van der Heide T, van Nes EH, Geerling GW, Smolders AJP, Bouma TJ, Katwijk MM (2007) Positive feedbacks in seagrass ecosystems-implications for success in conservation and restoration. Ecosystems 10:1311-1322

Editorial responsibility: Kenneth Heck Jr., Dauphin Island, Alabama, USA van Lent F, Verschuure JM (1994) Intraspecific variability of Zostera marina L. (eelgrass) in the estuaries and lagoons of the southwestern Netherlands. I. Population dynamics. Aquat Bot 48:31-58

Vaughan DE (1982) Production ecology of eelgrass (Zostera marina L.) and its epiphytes in Little Egg Harbor, New Jersey. PhD dissertation, Rutgers University, New Brunswick, NJ

Wassmann P, Duarte CM, Agusti S, Sejr MK (2011) Footprints of climate change in the Arctic marine ecosystem. Glob Change Biol 17:1235-1249

- Watanabe M, Nakaoka M, Mukai H (2005) Seasonal variation in vegetative growth and production of the endemic Japanese seagrass Zostera asiatica: a comparison with sympatric Zostera marina. Bot Mar 48:266-273

Wetzel RL, Penhale PA (1983) Production ecology of seagrass communities in the lower Chesapeake Bay. Mar Technol Soc J 17:22-31

Wium-Andersen S, Borum J (1984) Biomass variation and autotrophic production of an epiphyte-macrophyte community in a coastal Danish area. I. Eelgrass (Zostera marina L.) biomass and net production. Ophelia 23: $33-46$

Woodward FI, Williams BG (1987) Climate and plant distribution at global and local scales. Vegetatio 69:189-197

Wulff A, Iken K, Quartino ML, Al-Handal A, Wiencke C, Clayton MN (2009) Biodiversity, biogeography and zonation of marine benthic micro- and macroalgae in the Arctic and Antarctic. Bot Mar 52:491-507

Zimmerman RC, Smith RD, Alberte RS (1989) Thermal acclimation and whole-plant carbon balance in Zostera marina L. (eelgrass). J Exp Mar Biol Ecol 130:93-109

Submitted: January 14, 2014; Accepted: October 20, 2014 Proofs received from author(s): December 14, 2014 